\title{
PENERAPAN MODEL PEMBELAJARAN PROBLEM SOLVING DISERTAI KARTU SOAL UNTUK MENINGKATKAN KEMAMPUAN ANALISIS DAN PRESTASI BELAJAR SISWA PADA MATERI STOIKIOMETRI DI KELAS X MIPA 2 SEMESTER GENAP SMA BATIK 1 SURAKARTA
}

\author{
Apriliya Dwi Setyorini ${ }^{*}$, Agung Nugroho C S, dan Haryono \\ Program Studi Pendidikan Kimia, FKIP, Universitas Sebelas Maret, Surakarta, Indonesia \\ *Keperluan Korespondensi, telp: 085641571322, email: setyo_rini47@yahoo.co.id
}

\begin{abstract}
ABSTRAK
Penelitian ini bertujuan untuk meningkatkan: (1) kemampuan analisis siswa kelas X MIPA 2 pada materi stoikiometri di SMA Batik 1 Surakarta dengan menerapkan model pembelajaran Problem Solving disertai dengan kartu soal, dan (2) prestasi belajar siswa kelas X MIPA 2 pada materi stoikiometri di SMA Batik 1 Surakarta dengan menerapkan model pembelajaran Problem Solving disertai dengan kartu soal.Penelitian ini merupakan Penelitian Tindakan Kelas (PTK) yang dilakukan dalam dua siklus. Setiap siklusnya terdapat empat tahapan, yaitu perencanaan, pelaksanaan, observasi, dan refleksi. Subjek penelitian adalah siswa kelas X MIPA 2 SMA Batik 1 Surakarta tahun pelajaran 2016/2017. Teknik pengumpulan data melalui observasi, wawancara, kajian dokumen, angket dan tes. Teknik analisis yang digunakan dalam penelitian ini adalah deskriptif kualitatif. Berdasarkan hasil penelitian dapat disimpulkan bahwa: (1) penerapan model pembelajaran Problem Solving disertai dengan kartu soal dapat meningkatkan kemampuan analisis siswa kelas X MIPA 2 pada materi stoikiometri di SMA Batik 1 Surakarta tahun pelajaran 2016/2017. Pada siklus I, ketercapaian kemampuan analisis sebesar $41,86 \%$ dan pada siklus II meningkat menjadi 79,07\%, (2) penerapan model pembelajaran Problem Solving disertai dengan kartu soal dapat meningkatkan prestasi belajar pada siswa kelas X MIPA 2 pada materi stoikiometri di SMA Batik 1 Surakarta tahun pelajaran 2016/2017. Berdasarkan hasil tes siklus I ketercapaian aspek pengetahuan siswa sebesar $48,84 \%$ dan meningkat menjadi $83,72 \%$ pada siklus II. Ketercapaian aspek sikap pada siklus I sebesar $90,70 \%$ dan meningkat menjadi $100,00 \%$ pada siklus II. Ketercapaian aspek keterampilan sebesar $100,00 \%$ pada siklus I.
\end{abstract}

Kata kunci: Problem Solving, Kartu Soal, Kemampuan Analisis, Prestasi Belajar, Stoikiometri

\section{PENDAHULUAN}

Pembelajaran menurut Corey adalah suatu proses dimana lingkungan seseorang sengaja dikelola untuk memungkinkan ia turut serta dalam tingkah laku tertentu dalam kondisi khusus atau menghasilkan respon terhadap situasi tertentu. Sedangkan proses pembelajaran merupakan komunikasi dua arah, mengajar dilakukan oleh guru sebagai pendidik dan belajar dilakukan oleh siswa sebagai peserta didik [1]. Pada dasarnya pembelajaran adalah membangun gagasan atau pengetahuan siswa dengan cara berinteraksi dengan pendidik, informasi, peristiwa dan lingkungan disekitar siswa.
Kimia merupakan bagian dari IImu Pengetahuan Alam (IPA). Ada dua hal yang berkaitan dengan kimia yang tidak terpisahkan, yaitu kimia sebagai produk (pengetahuan kimia yang berupa fakta, konsep, prinsip, hukum dan teori) temuan ilmuan dan kimia sebagai proses (kerja ilmiah). Oleh sebab itu, pembelajaran kimia dan penilaian hasil belajar kimia harus memperhatikan karakteristik ilmu kimia sebagai proses dan produk [2]. Dapat disimpulkan pembelajaran kimia adalah interaksi antara siswa dan guru dalam membangun pengetahuan tentang materi pelajaran kimia dengan memperhatikan karakteristik ilmu kimia sebagai proses dan 
produk agar materi pelajaran kimia dapat tersampaikan dengan baik kepada siswa.

Proses pembelajaran pada Kurikulum 2013 menerapkan pendekatan saintifik atau scientific approach yaitu dengan komponen mengamati, menanya, mengumpulkan data, mengasosiasi dan mengkomunikasikan. Dalam proses pembelajaran pada Kurikulum 2013 berpusat pada peserta didik (Student Centered Learning) atau dengan kata lain peseta didik aktif mencari materi pembelajarannya sendiri, sehingga membuat suasana pembelajaran lebih aktif. Peran guru adalah sebagai fasilitator dan pembimbing peserta didik untuk menemukan makna belajarnya sendiri. Dalam pembelajaran yang terpenting adalah bagaimana siswa memperoleh suatu konsep pada kegiatan pembelajaran bukan pemindahan konsep dari guru kepada siswa.

Salah satu sekolah menengah atas di Surakarta yang menerapkan Kurikulum 2013 adalah SMA Batik 1 Surakarta. Berdasarkan observasi yang telah dilakukan, SMA Batik 1 Surakarta telah mererapkan Kurikulum 2013 dalam kegiatan belajar mengajarnya. Akan tetapi, dalam praktiknya belum sepenuhnya menerapkan Kurikulum 2013. Berdasarkan observasi yang telah dilakukan pembelajaran kimia di kelas juga masih berpusat pada guru (Teacher Centered Learning). Pembelajaran yang seperti ini membuat siswa kurang maksimal dalam menemukan konsep dari pembelajarannya sendiri. Hal ini juga mengakibatkan siswa kurang mampu dalam mengemukakan pendapat, menganalisis, serta mengaplikasikan konsep yang sudah diberikan. Hal tersebut mengakibatkan siswa kurang memahami konsep secara maksimal dan berimbas pula pada prestasi siswa pada prestasi belajar siswa.

Stoikiometri merupakan materi bab terakhir pada semester genap kelas $X$ dalam Kurikulum 2013. Menurut O. Daley Jr. \& O'Malley (1988) stoikiometri merupakan salah satu topik di dalam kimia yang mempelajari tentang bagaimana mencari produk dari suatu reaksi dengan mengasumsikan bahwa reaksi tersebut adalah satu-satunya yang terlibat dalam total keseluruhan produk [3]. Materi stoikiometri ini masih dianggap sulit karena dalam menyelesaikan soal siswa harus paham betul konsepnya dan dipadukan dengan perhitungan matematika. Siswa di Indonesia masih kesulitan untuk mengaitkan konsep-konsep pada materi stoikiometri jika sudah dihadapkan dengan soal [4]. Selain itu, materi stoikiometri termasuk materi yang memerlukan kemampuan analisis dalam menyelesaikan soal-soalnya. Pada penyelesaian soal, siswa dituntut untuk mengaitkan konsep-konsep yang sudah dipelajarinya. Hal ini yang menyebabkan materi stoikiometri dianggap sukar dan berimbas pula pada kualitas proses dan hasil pembelajaran.

Salah satu indikator bahwa materi stoikiometri dianggap sulit di SMA Batik 1 Surakarta adalah prestasi belajar yang kurang memuaskan dan hasil wawancara dengan guru mata pelajaran kimia di SMA Batik 1 Surakarta. Berdasarkan hasil wawancara dengan guru mata pelajaran kimia, banyak siswa kelas $\mathrm{X}$ yang mengalami kesulitan dalam materi stoikiometri. Hal ini karena materinya memang sulit, yaitu butuh pemahaman konsep dan perhitungan matematika. Kriteria Ketuntasan Minimal (KKM) yang diterapkan di SMA Batik 1 Surakarta sebesar 75 untuk semua mata pelajaran termasuk mata pelajaran kimia. Berdasarkan wawancara dengan guru kimia SMA Batik 1 Surakarta menyatakan bahwa prestasi belajar kelas X MIPA 2 masih rendah. Hal tersebut juga terlihat dari nilai rata-rata UAS Semester Gasal tahun pelajaran 2016/2017 kelas X MIPA 2 juga masih rendah yaitu 67,79 . Hal ini mengindikasikan adanya permasalahan dalam proses pembelajaran yang mengakibatkan prestasi belajar masih rendah.

Selain prestasi belajar yang masih rendah, dari observasi yang telah dilakukan, sebagian besar siswa masih kesulitan dalam menyelesaikan soal yang diberikan oleh guru. Siswa hanya mampu menyelesaikan soal seperti yang dicontohkan oleh guru dan akan merasa kesulitan jika diganti dengan soal yang 
bebeda dengan soal yang dicontohkan. Dalam mengerjakkan soal siswa belum menggunakan kemampuan analisis secara maksimal. Kemampuan analisis merupakan kemampuan untuk merinci atau menguraikan soal menjadi komponen-komponen yang lebih kecil serta mampu memahami hubungan diantara komponen-komponen tersebut. Komponen-komponen kemampuan analisis yaitu memeriksa suatu informasi atau ide, mengidentifikasi suatu pernyataan, dan mengidentifikasi suatu alasan dalam mengemukakan pendapat [5]. Selanjutnya, berdasarkan prasiklus yang telah dilakukan didapatkan data bahwa sebesar $62,79 \%$ siswa memiliki kemampuan analisis rendah, 25,58\% siswa memiliki kemampuan analisis sedang dan $11,63 \%$ siswa memiliki kemampuan analisis tinggi. Berdasarkan observasi dan prasiklus tersebut mengindikasikan bahwa kemampuan analisis siswa kelas X MIPA 2 masih cukup rendah dan perlu ditingkatkan.

Rendahnya prestasi belajar siswa dan kemampuan analisis siswa pada materi stoikiometri dapat disebabkan oleh beberapa faktor, salah satunya yaitu pemilihan model, metode, maupun media yang kurang tepat dengan karakterisrik siswa dan materi. Salah satu cara yang digunakan untuk meningkatkan kemampuan analisis dan prestasi belajar materi stoikiometri pada siswa adalah dengan menerapkan model pembelajaran Problem Solving. Menurut Crow dan Crow (1963) model pembelajaran Problem Solving atau pemecahan masalah adalah suatu cara menyajikan pelajaran dengan mendorong siswa untuk mencari dan memecahkan suatu masalah atau persoalan dalam rangka mencapai tujuan pembelajaran [6]. Langkahlangkah pembelajaran Problem Solving menurut Johnson dan Johnson (1979) yaitu: 1) Mendefinisikan masalah, 2) Mendiagnosis masalah, 3) Merumuskan alternatif strategi, 4) Menentukan dan menerapkan strategi, 5) Mengevaluasi keberhasilan strategi [7]. Berdasarkan langkah-langkah Problem Solving sangat dibutuhkan kemampuan analisis siswa untuk menyelesaikan soal. Oleh karena itu, model pembelajaran Problem Solving diharapkan dapat meningkatkan kemampuan analisis siswa. Selain itu, model pembelajaran Problem Solving selain melatih siswa untuk menghadapi masalah dalam hal ini adalah soal-soal, model ini juga dianggap lebih sistematis dan memudahkan siswa dalam memahami konsep lewat masalah yang berupa soal.

Selain menggunakan model yang tepat, pengunaan media dalam pembelajaran juga diperlukan sebagai pembawa informasi dari guru kepada siswa. Dalam penelitian ini media yang digunakan adalah Kartu Soal. Kartu Soal ini berisi latihan-latihan soal materi stoikiometri yang dibuat setiap satu soal satu kartu dan terdapat tata cara penggunaan kartu sehingga dapat menambah minat siswa dalam belajar dan berlatih soal. Materi stoikiometri merupakan materi yang memerlukan latihan soal yang bertujuan untuk memberikan situasi baru kepada siswa sehingga siswa dapat mengaitkan antar konsep pada materi stoikiometri. Pengguaan kartu soal ini juga dapat meningkatkan kemampuan analisis siswa karena kartu berisi soal-soal yang mengharuskan siswa mengoptimalkan kemampuan analisisnya.

Berdasarkan latar belakang rendahnya ketuntasan siswa X MIPA 2 materi stoikiometri dua tahun yang lalu, tingkat kesulitan materi stoikiometri, kemampuan analisis siswa yang masih rendah serta partisipasi siswa dalam pembelajaran masih kurang, maka peneliti bermaksud mengadakan penelitian dengan judul "Penerapan Model Pembelajaran Problem Solving Disertai Kartu Soal untuk Meningkatkan Kemampuan Analisis dan Prestasi Belajar Siswa pada Materi Stoikiometri di Kelas X MIPA 2 Semester Genap SMA Batik 1 Surakarta"

\section{METODE PENELITIAN}

Penelitian ini merupakan Penelitian Tindakan Kelas (PTK) yang dilaksanakan dalam dua siklus. Setiap siklusnya terdapat empat tahapan, yaitu perencanaan, pelaksanaan, observasi, dan refleksi. Subjek penelitian adalah 
siswa kelas X MIPA 2 SMA Batik 1 Surakarta tahun pelajaran 2016/2017. Pemilihan subjek dalam penelitian ini didasarkan pada hasil observasi dan prasiklus, dimana subjek yang dipilih tersebut teridentifikasi mempunyai permasalahan dalam pembelajaran yaitu kemampuan analisis dan prestasi belajar yang rendah.

Data yang dikumpulkan meliputi data dari hasil tes kemampuan analisis, hasil penilaian prestasi belajar pada materi stoikiometri yang meliputi aspek pengetahuan, aspek sikap, dan keterampilan baik pada siklus I maupun siklus II.

Teknik analisis data pada penelitian ini menggunakan analisis deskriptif kualitatif. Analisis data menggunakan tiga tahap yaitu reduksi data (pemilihan data), penyajian data (mengorganisasi-kan data melalui penyusunan informasi secara sistematik), dan penarikan kesimpulan [8].

\section{HASIL DAN PEMBAHASAN}

Penelitian tindakan kelas ini bertujuan untuk meningkatkan kemampuan analisis dan prestasi belajar siswa kelas X MIPA 2 SMA Batik 1 Surakarta pada materi stoikiometri dengan menerapkan model pembelajaran Problem Solving disertai dengan kartu soal. Prestasi belajar yang diukur meliputi aspek pengetahuan, sikap dan keterampilan.

Penelitian ini dilakukan dalam 2 siklus yaitu siklus I dan siklus II. Masingmasing siklus terdiri dari tahap perencanaan, tahap pelaksanaan tindakan, tahap observasi dan tahap refleksi. Proses pembelajaran menggunakan model Problem Solving disertai kartu soal ini dilakukan dalam kelompok untuk memberikan pengalaman belajar dengan cara menyelesaikan masalah atau soal yang telah diberikan oleh guru bersama dengan kelompoknya.

Pada tahap perencanaan siklus I dilakukan penyusunan silabus, RPP, kartu soal, instrumen penilaian kemampuan analisis siswa, serta instrumen prestasi belajar. Berdasarkan data silabus diketahui bahwa materi staoikiometri memiliki alokasi waktu 8 jam pelajaran (8 jp). Perincian pembelajaran pada siklus I yaitu 6 jp (4 kali pertemuan) untuk penyampaian materi dan 2 jp (satu kali pertemuan) untuk evaluasi siklus I.

Pelaksanaan tindakan pada siklus I mulai dilaksanakan pada tanggal 20 April 2017. Pada pembelajaran menggunakan model pembelajaran Problem Solving disertai dengan kartu soal ini siswa dibagi menjadi 9 kelompok yang terdiri dari 4 sampai 5 siswa. Penerapan model pembelajaran Problem Solving disertai dengan kartu soal ini diharapkan dapat meningkatkan prestasi belajar siswa juga dapat meningkatkan kemampuan analisis siswa. Pada siklus I pembelajaran dilaksanakan 4 kali pertemuan penyampaian materi dan 1 kali pertemuan untuk evaluasi. Evaluasi yang dilakukan meliputi tes kemampuan analisis, tes aspek pengetahuan, pengisian angket aspek sikap dan penilaian aspek keterampilan.

Observasi terhadap siswa dilakukan selama proses pembelajaran. Pada pertemuan pertama masih terdapat beberapa siswa yang kurang fokus dalam mengikuti pembelajaran. Selain itu juga terdapat beberapa kelompok yang masih merasa kesulitan dalam memecahkan soal yang berkaitan dengan materi yang sedang diajarkan. Hal ini dikarenakan siswa belum terbiasa menerapkan model pembelajaran Problem Solving dimana siswa dituntut aktif untuk memecahkan permasalah berupa soal-soal. Akan tetapi, pada pertemuan kedua dan seterusnya siswa mulai terbiasa dengan model pembelajaran Problem Solving dan siswa lebih aktif dalam menganalisis serta menyelesaikan soal-soal yang telah diberikan oleh guru berkaitan dengan materi stoikiometri.

Berdasarkan hasil refleksi pada aspek pengetahuan belum memenuhi target ketuntasan. Kemampuan analisis siswa pada siklus I juga belum memenuhi target ketuntasan. Pada aspek sikap sudah mencapai ketuntasan. Kemudian pada aspek keterampilan juga sudah memenuhi target ketuntasan. Oleh karena itu perlu adanya tindakan perlu adanya tindakan 
pada siklus II sehingga persentase ketercapaian seluruh indikator dapat tercapai semua dan kekurangan pada siklus I dapat diperbaiki dan ditingkatkan pada siklus II. Aspek yang akan diperbaiki pada siklus II adalah aspek pengetahuan dan kemampuan analisis serta aspek yang ditingkatkan pada siklus II adalah aspek sikap. Aspek keterampilan tidak diujikan lagi di siklus II karena ketercapaian aspek keterampilan sudah $100 \%$.

Pembelajaran siklus II direncanakan terdiri dari 2 kali pertemuan, yaitu 1 kali pertemuan (2JP) untuk penyampaian materi dan 1 kali pertemuan (2JP) untuk evaluasi siklus II. Secara umum, kegiatan pembelajaran dengan model pembelajaran Problem Solving disertai dengan kartu soal sama dengan kegiatan pembelajaran pada siklus I. Perbedaannya terletak pada kelompok diskusi, serta bimbingan yang lebih intensif serta motivasi lebih dari guru saat pembelajaran berlangsung.

Pelaksanaan siklus II ini lebih difokuskan untuk perbaikan terhadap kendala-kendala yang muncul pada siklus I. Tindakan yang dimaksud yaitu, guru lebih memfokuskan pada siswa yang pada evaluasi siklus I mendapatkan nilai yang tergolong rendah dibandingkan teman-temannya serta guru lebih memberikan bimbingan saat diskusi agar siswa lebih paham tentang materi yang dianggapnya sulit, guru juga memberikan motivasi kepada siswa agar siswa lebih aktif dalam bertanya dan menyampaikan pendapatnya, serta perbaikan juga dilakukan terkait dengan pembagian kelompok untuk diskusi. Kelompok diskusi pada siklus II ini dibagi berdasarkan nilai yang telah didapat siswa pada evaluasi siklus I.

Pada akhir siklus II dilakukan tes yang meliputi tes kemampuan analisis, tes aspek pengetahuan, serta pengisian angket aspek sikap, observasi aspek afektif dilakukan pada saat pembelajaran dan wawancara dilaksanakan jika nilai siswa belum bisa diambil modusnya.

Data yang diperoleh dalam penelitian adalah kemampuan analisis dan prestasi belajar siswa pada materi stoikiometri. Data penelitian mengenai kemampuan analisis secara ringkas dapat diketahui bahwa persentase kemampuan analisis siswa yang berkategori sedang dan tinggi mengalami peningkatan. Hal ini menunjukkan bahwa kemampuan analisis siswa mengalami peningkatan pada siklus I ke siklus II. Data kemampuan analisis disajikan pada Tabel 1.

Tabel 1. Hasil Penilaian Kemampuan Analisis Siklus I dan Siklus II

\begin{tabular}{ccc}
\hline \multirow{2}{*}{ Kriteria } & \multicolumn{2}{c}{ Capaian (\%) } \\
\cline { 2 - 3 } & Siklus I & Siklus II \\
\hline Tinggi & 6,98 & 25,58 \\
Sedang & 34,88 & 53,49 \\
Rendah & 58,14 & 20,93 \\
\hline
\end{tabular}

Berdasarkan Tabel 1 dapat dilihat bahwa persentase kemampuan analisis pada siklus I yang masuk dalam kategori sedang sebanyak 15 siswa $(34,88 \%)$ dan kategori tinggi sebanyak 3 siswa (6,98\%). Target untuk kemampuan analisis adalah minimal $60 \%$ jumlah siswa masuk dalam kategori sedang. Berdasarkan persentase tersebut jumlah siswa yang masuk kategori sedang dan tinggi sejumlah $41,86 \%$. Hal tersebut menunjukkan bahwa kemampuan analisis siswa pada siklus I belum tercapai. Hal tersebut dikarenakan siswa masih mengalami kesulitan dalam mengerjakan soal-soal pada tes kemampuan analisis. Ketiga indikator dari aspek kemampuan analisis yang belum mencapai target yaitu menguraikan informasi ke dalam komponennya untuk memberikan keputusan, mengidentifikasi suatu informasi dan menentukan alternatif-alternatif yang tepat di dalamnya, dan menentukan suatu penyelesaian dari masalah atau pernyataan dengan mengemukakan pendapat.

Pada siklus II terdapat peningkatan hasil yaitu siswa dengan kemampuan analisis tinggi sebanyak 11 siswa $(25,58 \%)$, siswa dengan kemampuan analisis sedang sebanyak 23 siswa $(53,49 \%)$, serta siswa dengan kemampuan analisis rendah sebanyak 9 siswa $(20,93 \%)$. Berdasarkan persentase tersebut jumlah siswa yang masuk kategori sedang dan tinggi sejumlah 
$79,07 \%$. Selain itu, ketiga indikator kemampuan analisis juga sudah mencapai target. Salah satu faktor yang dapat meningkatkan kemampuan analisis siswa adalah penerapan model pembelajaran Problem Solving disertai kartu soal. Penerapan model pembelajaran Problem Solving disertai dengan Kartu Soal dapat meningkatkan kemampuan analisis siswa. Hal ini dikarenakan langkah-langkah dalam model pembelajaran ini memerlukan analisis dalam pelaksanaan memecahkan masalah atau soal. Kemampuan analisis ini berupa kemampuan siswa dalam menentukan strategi yang sistematis agar masalah atau soal dapat terpecahkan. Oleh karena itu, penerapan model pembelajaran Problem Solving dapat meningkatkan kemampuan analisis siswa.

Aspek pengetahuan pada siklus I ketuntasan yang diperoleh yaitu sebesar $48,84 \%$. Sedangkan target ketuntasan yang ditentukan adalah sebesar $65 \%$. Hal tersebut menunjukkan bahwa siklus I belum mebcapai target. Selain itu, terdapat 4 indikator kompetensi yang belum mencapai target yaitu menentukan rumus empiris dan rumus molekul suatu zat, menentukan kadar zat, massa zat terlarut dan massa larutan, menentukan kadar zat, volume zat terlarut, dan volume laruran, serta menghitung fraksi mol suatu zat. Adanya indikator kompetensi yang belum mencapai target dikarenakan siswa belum memahami dengan baik materi pada indikator tersebut serta siswa masih kesulitan jika dihadapkan pada variasi soal yang berbeda serta siswa juga kurang aktif dalam menanyakan kepada guru tentang materi mana saja yang belum dipahami sehingga dalam mengerjakan soal masih banyak siswa yang salah menjawab. Oleh karena itu, penelitian harus dilanjutkan ke siklus II.

Pada siklus II terdapat 36 siswa $(83,72 \%)$ siswa yang tuntas dan semua indikator tercapai. Hal tersebut pada siklus II mengalami peningkatan ketuntasan dan semua indikator sudah mencapai target.
Adapun ketercapaian aspek pengetahuan pada siklus I dan siklus II dapat dilihat pada Tabel 2 .

Tabel 2. Hasil Penilaian Aspek Pengetahuan Siklus I dan Siklus II

\begin{tabular}{ccc}
\hline \multirow{2}{*}{ Indikator } & \multicolumn{2}{c}{ Capian (\%) } \\
\cline { 2 - 3 } & Siklus I & Siklus II \\
\hline 2 & 72,09 & 100 \\
3 & 100 & - \\
4 & 100 & - \\
5 & 83,72 & 86,05 \\
6 & 19,77 & 74,42 \\
7 & 56,98 & 65,12 \\
8 & 23,26 & 81,40 \\
9 & 79,07 & 97,67 \\
10 & 72,09 & 74,42 \\
11 & 100 & - \\
12 & 76,74 & 90,70 \\
13 & 30,23 & 76,74 \\
\hline
\end{tabular}

Berdasarkan Tabel 2. dapat diketahui bahwa pada siklus II mengalami peningkatan ketuntasan tiap indikator kompetensi. Selain peningkatan ketuntasan siswa secara keseluruhan, akan tetapi terdapat peningkatan pula pada tiap indikator kompetensi. Hal tersebut menunjukkan bahwa model pembelajaran Problem Solving disertai kartu soal dapat meningkatkan prestasi belajar siswa kelas X MIPA 2.

Penilaian aspek sikap yang diberikan berupa angket, observasi dan wawancara untuk mengukur aspek spiritual, jujur, kerjasama, disiplin dan percaya diri. Target yang ditetapkan pada aspek sikap ini adalah $75 \%$ siswa berada dalam kategori baik (B). Ketercapaian dari aspek sikap sudah mencapai target yaitu 90,70\%. Akan tetapi, pada siklus II tetap diujikan kembali untuk melihat apakah ada peningkatan pada aspek sikap. Pada siklus II terjadi peningkatan sebesar $9,30 \%$ atau dengan kata lain $100 \%$ siswa sudah tuntas pada aspek sikap.

Adapun persentase hasil penilaian tiap aspek sikap pada siklus I dan siklus II dapat dilihat pada Tabel 3. 
Tabel 3. Hasil Penilaian Tiap Aspek Sikap Siklus I dan Siklus II

\begin{tabular}{ccc}
\hline \multirow{2}{*}{ Aspek } & \multicolumn{2}{c}{ Capaian (\%) } \\
\cline { 2 - 3 } & Siklus I & Siklus II \\
\hline Spiritual & 86,05 & 95,35 \\
Jujur & 79,07 & 93,02 \\
Kerjasama & 93,02 & 93,02 \\
Disiplin & 90,70 & 93,02 \\
Percaya Diri & 83,72 & 88,37 \\
\hline
\end{tabular}

Berdasarkan Tabel 3. dapat dilihat bahwa hampir semua aspek meningkat pada siklus II. Pada aspek kerjasama tidak mengalami penurunan juga tidak mengalami peningkatan. Akan tetapi pada aspek yang lainnya mengalami peningkatan pada siklus II.

Pada aspek keterampilan, penilaian diambil dari keterampilan siswa dalam mengolah dan menganalisis data, membuat laporan dan menyajikan data. Penilaian keterampilan siswa sebesar $100 \%$ siswa sudah mendapatkan nilai minimal 75 dimana sesuai dengan target yang sudah direncanakan. Penilaian prestasi belajar aspek keterampilan dilakukan hanya dalam satu siklus karena sudah mencapai target ketuntasan siswa dan untuk setiap indikatornya.

Berdasarkan hasil di atas, dapat disimpulkan bahwa penggunaan model pembelajaran Problem Solving disertai kartu soal dapat meningkatkan kemampuan analisis siswa dan prestasi belajar siswa dari aspek pengetahuan, sikap. Penelitian yang dilakukan diakhiri karena seluruh aspek, yaitu kemampuan analisis, pengetahuan, sikap, dan keterampilan sudah mencapai target yang telah ditentukan.

\section{Perbandingan Hasil Siklus I dan Siklus II}

Pada pembelajaran dengan model Problem Solving disertai dengan kartu soal terjadi peningkatan dari siklus I ke siklus II. Hasil tindakan siklus I dan siklus II disajikan pada Gambar 1.

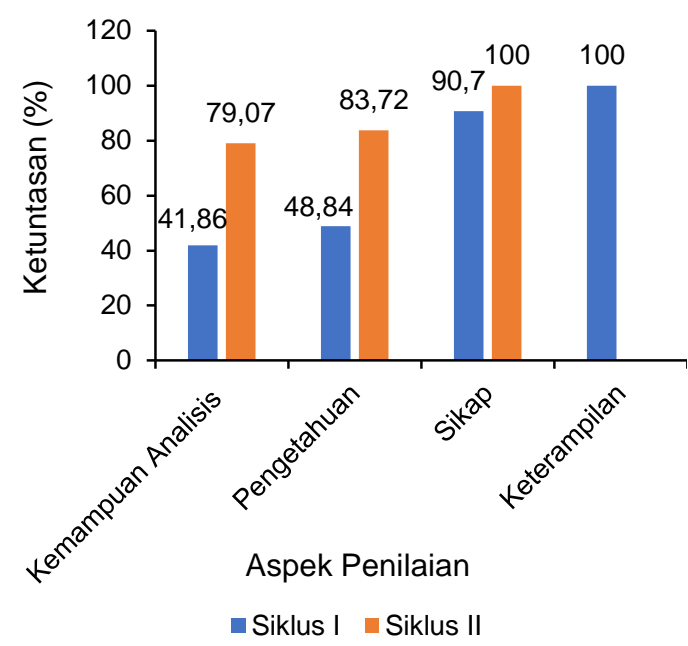

Gambar 1. Histogram Ketercapaian Aspek Penilaian Siklus I dan Siklus II

\section{KESIMPULAN}

Berdasarkan hasil penelitian yang telah dilakukan, maka dapat disimpulkan bahwa penerapan model pembelajaran Problem Solving disertai dengan kartu pada materi stoikiometri kelas X MIPA 2 SMA Batik 1 Surakarta tahun pelajaran 2016/2017 dapat meningkatkan kemampuan analisis dan prestasi belajar siswa. Persentase ketercapaian kemampuan analisis siswa pada siklus I sebesar $41,86 \%$ menjadi $79,07 \%$ pada siklus II. Peningkatan prestasi belajar siswa juga terlihat dari hasil prestasi belajar aspek pengetahuan sebesar $48,84 \%$ menjadi $83,72 \%$. Aspek sikap sebesar 90,70\% meningkat menjadi $100 \%$. Ketercapaian aspek keterampilan sebesar $100 \%$.

\section{UCAPAN TERIMA KASIH}

Penelitian ini dapat terselenggara dengan baik karena bantuan dari berbagai pihak. Oleh karena itu penulis ingin mengucapkan terimakasih kepada Kepala SMA Batik 1 Surakarta, Bapak Drs. H. Literzet Sobri, M.Pd. atas izin yang diberikan kepada penulis untuk melakukan penelitian, dan kepada guru kimia kelas X Ibu Ugik Sugiharti, S.Pd., M.Pd. yang telah memberikan bimbingan selama penelitian, serta kepada siswasiswi kelas X MIPA 2 SMA Batik 1 Surakarta tahun pelajaran 2016/2017 yang telah membantu penulis dalam menyelesaikan penelitian ini. 


\section{DAFTAR RUJUKAN}

[1] Sagala, S. (2010). Konsep dan Makna Pembelajaran. Bandung: Alfabeta.

[2] Mulyasa, E. (2007). Kurikulum Tingkat Satuan Pendidikan: Sebuah Panduan Praktis. Bandung: Remaja Rosdakarya.

[3] Hafsah, T., Rosnani, H., Zurida, I., Kamaruzaman, \& J., Khoo Yin Y. (2014). Scottish Journal of Arts, Social Sciences and Scientific Studies, 21 (1) 3-21.

[4] Agung, S \& Marc S. Schwartz. (2007). International Journal of Science Education, 29 (13) 16791702.
[5] Facione, P.A. (2011). Critical Thinking: What It is and Why It Count. Measured Reason and The California Academic Press. Millbrae, CA.

[6] Hamdani. (2011). Strategi Belajar Mengajar. Bandung: Pustaka Setia

[7] Gulo, W. (2002). Strategi BelajarMengajar. Jakarta. Gramedia Widiasarana Indonesia.

[8] Sugiyono. (2010). Metode Penelitian Pendidikan. Bandung: Alfabeta. 